JOURNAL OF VETERINARY MEDICAL RESEARCH 2017, 24 (1): 103-113

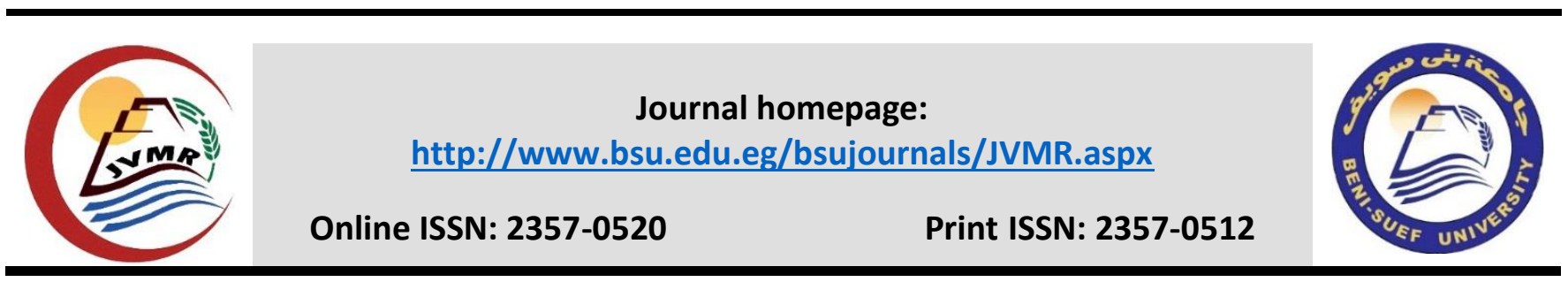

Original Research Article

\title{
Pathogenicity and immunosuppressive potential of an Egyptian field isolate (2015) of the chicken anemia virus (CAV) in chickens
}

\author{
Nassif, S.A. , Anhar A. Abdel Latif, Nermeen M. Elsayed, Hayam Farouk, Ekram Salama, \\ Ghada M. Elsadek
}

Central Laboratory for Evaluation of Veterinary Biologics, Abbasia, Cairo Egypt

\section{ABSTRACT}

Chicken anemia virus (CAV) is the causative agent of chicken infectious anemia (CIA). Studying CAV isolates in Egypt and their genetic diversity and its potential role in vaccination failure recently noticed in broiler flocks, is lacking in Egypt. So, the present study aimed to characterize CAV isolate-collected from a commercial broiler flock suffered from severe anemia and high mortality based on sequence and phylogenetic analysis of partial VP1 gene as well as to study pathogenicity and immunosuppressive potential in one day-old SPF chicks. The CAV isolate proved to be positive by PCR. The PCR product was sequenced and submitted to the gene bank under the accession number KX171350 and the CAV strain was designated as CLEVB-Zag2. Phylogenetic analysis at the nucleotide and amino acids level classify CLEVB-Zag2 CAV under group III (genotype III) of CAVs. On the other hand, the CLEVB-Zag2 CAV was found to be highly pathogenic for the experimentally inoculated SPF- chicks showing depression, severe anemia in almost all chicks in two infected groups beginning at the 7th day post infection (PI) and reached the peak of severity at the 14th day (hematocrit value, hemoglobin conc. and RBCs counts) are significantly reduced in chicks of the infected group. Blue wings were observed in few chicks in each infected group at the 14th day PI. Macroscopic lesions consisting of subcutaneous and muscular hemorrhages are observed with pale bone marrow, significant atrophy of thymus, spleen and bursa, hepatomegally with mottled liver and paleness of the carcasses were detected 7 days $\mathrm{PI}$ Those findings were evident and increased in severity until the day $14 \mathrm{PI}$. Concerning the CLEVB-Zag2 CAV, it was found to be highly immunosuppressive in the infected SPFchicks vaccinated with a commercial potent inactivated $\mathrm{H} 5 \mathrm{~N} 1$ vaccine as manifested by a significant reduction (protection 50\%). The variance in the titer of the shieded challenge $\mathrm{H} 5 \mathrm{~N} 1$ virus was $1.45 \log 10$ and the mean $\mathrm{HI}$ titer at the 4 th week post vaccination was $1.5 \log 2$ compared with the non-infected vaccinated group where these values were $90 \%, 2.35 \log 10$ and $5.3 \log 2$; respectively. In conclusion, the present study revealed that the CLEVB-Zag2 CAV isolate is highly pathogenic and immunosuppressive.

\section{ARTICLE INFO}

Article history:

Received: 5

2017

Accepted: 62017

Available Online: 62017

\section{Keywords:}

Pathogenicity, field isolate, Immunosuppressive potential, Chicken infectious anemia virus, Egypt 


\section{Introduction}

Chicken anemia virus (CAV) is a ubiquitous and highly resistant virus of chickens that causes anemia and death in chicks less than 3 weeks of age and immune suppression in chickens older than 3 weeks of age (Miller et al., 2003). CAV is a small spherical, non-enveloped virus containing a circular single stranded DNA genome (Pope, 1991).

CAV was recorded in different countries allover the world (England, Mexico, Belgium, Brazil, Taiwan, Argentina, China, Israel, Nigeria, Greece, Malaysia, New Zealand, Iran, Turkey and India (Pope, 1991, Yong et al., 1993; Buscaglia et al., 1994; Zhou et al., 1997; Ledesma et al., 2001; Davidson et al., 2004; Oluwayelu et al., 2005; Bougiouklis et al., 2007; Hailemariam et al., 2008).

CAV infection in chickens is characterized by severe anemia, intramuscular hemorrhage, destruction of RBCs in the bone marrow, low hematocrite value and reduced body weight. CAV is an immunosuppressive agent and its major pathological effect is seen in the thymus (Pope, 1996).

The present study was planned to fulfill the following Detection of CAV in suspected field samples by PCR assay, Molecular characterization of the predicted isolate detected by PCR using gene sequencing followed by phylogenesis, Studying the pathogenicity of the predicted isolate of CAV in one day old SPF chicks and Studying the potential immune-suppression of the isolated CAV in chickens vaccinated with inactivated AI vaccine, via determining the post vaccination immune response $(\mathrm{HI})$, and the protection percentage in both vaccinated infected and vaccinated non infected groups.

\section{Materials and methods \\ Chicken Anemia Virus isolate}

Thymus glands were collected from a 30 day old broiler chickens flock suffered from severe anemia and stunting. The thymuses were ground with PBS (pH 7.2) containing $1000 \mathrm{IU} / \mathrm{ml}$ penicillin and $10 \mathrm{mg}$ streptomycin at $2 / 10(\mathrm{~W} / \mathrm{V})$ and subjected to 3 cycles of freezing and thawing, centrifuged and filtered through 0.45 micron millipore filter. The filtrate was kept at $-20^{\circ} \mathrm{C}$ till used.

\section{DNA Extraction and PCR Amplification}

Viral DNA was extracted from the filterate by QIAamp DNA mini kit (Qiagen Inc., Valencia, CA) according to the manufacturer's instructions. The primers 5' -GAC TGT AAG ATG GCA AGA CGA GCT C-3' and 5' -GGC TGA AGG ATC CCT CAT TC-3' were used to amplify a 675 bp DNA fragment of VB1 (Todd et al., 1995). The PCR assay was performed using 2X Master mix (Biomatik company cat. number A4145 - lot number 067) kit according to the manufacturer's instructions in a final volume of $50 \mu \mathrm{l}$ Brefly, $25 \mu \mathrm{l}$ of the master mix, $18 \mu \mathrm{l}$ PCR grade water, $1 \mu \mathrm{l}$ of each primer, and $5 \mu$ template. The PCR conditions were: one cycle of initial denaturation at $94{ }^{\circ} \mathrm{C}$ for $5 \mathrm{~min}$ followed by 34 cycles of $94{ }^{\circ} \mathrm{C}$ for $1 \mathrm{~min}, 56{ }^{\circ} \mathrm{C}$ for $1 \mathrm{~min}$, and $72{ }^{\circ} \mathrm{C}$ for $1 \mathrm{~min}$. and finally one cycle of final extension at $72{ }^{\circ} \mathrm{C}$ for $7 \mathrm{~min}$.

\section{Sequencing and phylogenetic analysis}

The PCR product was submitted to a commercial company (Sigma) to be sequenced in both directions. The obtained sequence was submitted to the Gene Bank and the isolate was designated as CLEVBZag2 CAV under the accession number KX171350. Phylogenetic analysis was done using DNA star version 6.

\section{Avian influenza vaccine and challenge highly} pathogenic avian influenza (HPAI) H5N1 virus

A commercial inactivated oil adjuvenated H5N1 AI vaccine was used for vaccination of experimental chicks. HPAI H5N1 virus strain A/duck/Egypt/CLEVB-24_N00238/2015 of accession number EPI579780 was supplied by CLEVB and used to challenge experimentally vaccinated chicks.

\section{Chickens}

One hundred, one-day-old specific pathogen-free (SPF) chickens free form CAV and CAV antibodies (Koum Osheim, Egypt) were divided into 3 groups each of 33 chicks and housed in BSL3 chicken isolators throughout an experimental period of 38 days.

\section{Experimental design}

On day one of age, each chick of group (1) and (2) was inoculated intra-muscular with $0.2 \mathrm{ml}$ of the collected thymus homogenate, while chicks of group

(3) were kept as non- inoculated negative control. At the 7th and 14th days post infection, 5 chickens were selected randomly from groups (1) and (3), clinically 
examined and weighed. Heparinized blood samples were obtained individually from the jugular vein for haematocrit values and the other hematological values. Subsequently, birds were euthanized and examined for gross-pathological changes. Liver, thymus, bursa and spleen were collected and weighed individually. Weights and hematological values were analyzed by a Fisher test. Samples were then obtained from each organ and fixed in $10 \%$ buffered formalin for histopathological examination. Additional samples were obtained and stored frozen for virus detection by PCR. At the $14^{\text {th }}$ day of age, chicks of groups (1) and (2) were vaccinated against avian influenza using $0.5 \mathrm{ml}$ of a commercial H5N1 AI vaccine via the subcutaneous route. Blood samples were collected randomly from 10 chickens of each group weekly till the $4^{\text {th }}$ week post vaccination; where 20 chickens from each group were challenged via the intranasal rout with $0.1 \mathrm{ml}$ of the 2015 HPAI H5N1 virus strain (A/duck/Egypt/CLEVB-24_N00238/2015 of accession number EPI579780). Challenged chickens were observed for 10 days, both clinical signs, morbidity and mortalities were recorded. Oropharyngeal swabs were collected individually for detection of virus shedding, from the chickens of each challenged group at the $3 \mathrm{rd}, 5$ th, 7 th and 10th days post challenge.

\section{HPAI virus shedding detection and quantification}

Swabs samples were resuspended in $1 \mathrm{ml}$ PBS containing 1000 IU penicillin and 1000ug streptomycin by cutting the cotton part in cryo-vial and doing vigorous vortexing. Supernatant fluids were transferred to new vials then viral RNA extraction was done using Qiagen RNase extraction kit according to the manufacturer's instructions, then real time Rt-PCR were conducted using Real time RT-PCR kit (Invitrogen, USA). The primers, probe and cycle conditions were according to Löndt et al. (2008). The shedding titer (PCR copies $/ \mathrm{ml}$ ) was conducted targeting the $\mathrm{M}$ gene and results of CT values were calculated against challenge virus standard curve. Mean shedding titer $=$ sum of shedding titers/number of shedder birds.

\section{Heamagglutination and heamagglutination inhibition (HA and HI) tests}

The post vaccination chicken immune response monitoring was conducted using $\mathrm{HI}$ test according to OIE Manual (2013), using standard 4 HAU of the homologous antigen. Data of $\mathrm{HI}$ testing were analyzed based on geometric mean titer and standard deviation (SD).

\section{Histopathology}

Liver, spleen, thymus and bone marrow samples of birds in different groups were fixed in $10 \%$ formol-saline until histopathological examination and stained by hematoxylin and eosin then examined through the light electric microscope according to Bancroft et al. (1996).

\section{Results}

Clinical signs and PM of the affected broiler flock

The examined broiler flock showed depression and paleness (Anemia), uneven growth with high mortality $(60 \%)$ which start at the $18^{\text {th }}$ day of age and continued till the slaughter time $\left(35^{\text {th }}\right.$ day of age). Dead birds showed atrophied thymus and bursa, enlarged and mottled liver, subcutaneous and muscular hemorrhages, fatty and yellowish bone marrow of the femur and finally skin lesions "blue wings disease" (Figs. 1-4).

\section{PCR result}

The $675 \mathrm{bp}$ amplicon of the VP1 of CAV was detected by PCR in the thymus homogenate of the examined broiler flock indicating CAV infection (Fig. 5). The PCR product was sequenced and submitted to the gene bank under the accession number KX171350 and the CAV strain was designated as CLEVB-Zag2.

\section{Phylogenetic analysis}

Phylogenetic analysis at the nucleotide and amino acid levels classify CLEVB-Zag2 CAV under group III (Genotype III). On the other hand, the CLEVBZag2 CAV was found to be $100 \%$ identical to 2 CAV from India of accession numbers KJ620993 and KJ620995 and one CAV isolate from South Korea of accession number HM018735 and Finally the vaccinal strain Noblis P4.

\section{Pathogenicity}

Clinical signs in the form of depression, anorexia, dehydration, uneven growth and anemia were observed on almost all chicks in the two infected groups beginning at the $7^{\text {th }}$ day post infection (PI) and reached the peak of severity at the $14^{\text {th }} \mathrm{PI}$ (Hematocrit value, Hemoglobin conc. and RBCs counts are significantly reduced in the chicks of the infected group (Table 1). Blue wings were observed on few chicks in each infected group at the $14^{\text {th }}$ day PI, at the same period, macroscopic lesions in the 
form of subcutaneous and muscular hemorrhages were observed with pale bone marrow, significant atrophy of thymus, spleen and bursa, hepatomegally with mottled liver and paleness of the carcasses were detected 7 days p.i. These findings were evident until day 14 PI where it increased in severity (Figs. 6-9 and Table 2).

Microscopically, after 7 days, the portal area of the liver of the experimental chicks showed severe congestion in the portal vein associated with focal necrosis as well as inflammatory cells infiltration (Fig. 10A and 10B). The thymus showed lymphoid depletion in both cortical and medullary portions with congestion in the blood vessel (Fig. 10C). The spleen showed lymphoid depletion in the white pulps while the red one had congestion (Fig. 10D). Finally, the bone marrow showed severe depletion in the erythrocytes as well as the other haemoblasts (Fig. 10E). At the 14th day PI, focal lymphoid cell aggregations were detected in the hepatic parenchyma (Fig. 11A) with sever dilatation and congestion in the portal vein (Fig. 11B).In the thymus, there was depletion in both cortical and medullary lymphoid structure (Fig. 11C). The spleen showed focal necrosis in diffuse manner allover the white pulps (Fig. 11D).Finally, the Bone marrow showed sever depletion in diffuse manner allover the erythrocytes as well as the haemoblasts with inflammatory cells infiltration (Fig. 11E).

\section{Immunosuppressive potential}

Severe immunosuppression was detected in the CAV infected SPF chicken group as manifested by significant reduction in the protection percentage $(50 \%)$, the variance in the titer of the shielded challenge $\mathrm{H} 5 \mathrm{~N} 1$ virus $(1.45 \log 10)$ and the mean $\mathrm{HI}$ titer at the $4^{\text {th }}$ week PV (1.5 log2) compared with the non-infected vaccinated group where these values were $90 \%, 2.35 \log 10$ and $5.3 \log 2$, respectively (Tables 3-5).

\section{Discussion}

CAV has been reported to cause disease in young chicks aged one day to 4 weeks. In older chickens CAV infection has been reported to be subclinical (McNulty, 1991). The present examined broiler flock showed anemia, uneven growth with high mortality $(60 \%)$ which start at the $18^{\text {th }}$ day of age and continued till the slaughter time $\left(35^{\text {th }}\right.$ day of age).The dead birds showed atrophied thymus and bursa, enlarged and mottled liver, subcutaneous and muscular hemorrhages, fatty and yellowish bone marrow of the femur and finally skin lesions "blue wings disease"(Figs.1-4). These results are similar to those of Yuasa et al., (1979, 1983, 1987), von Bülow et al. (1983, 1986), McNulty et al. (1989, 1990), McNulty (1991) and Noteborn et al. (1991, 1992). In the same context the observed high mortalities in the examined flock could be due to the immunosuppressive effect of CAV that lead to vaccination failure and aggravation of the pathogenicity of other avian pathogens (secondary infections), as reported by Von Bülow et al. (1986), Yuasa et al. (1987), Engström (1988), Otaki et al. (1988), Rosenberger and Cloud (1989), de Boer et al. (1992), McNulty et al. (1991), McIlroy et al. (1992), Jeurissen and de Boer (1993), Sommer and Adair (2000), Cardona (2003) and Davidson et al. (2004).

CAV was detected by PCR in the examined broiler flock and the amplified PCR product, which represent partial VP1 gene, was sequenced and the CAV strain was designated as CLEVB-Zag2 with accession number KX171350 at the gene bank. Phylogenetic analysis at the amino acids and nucleotide level of VP1 classify CLEVB-Zag2 CAV under group III (Genotype III) of the CAV in agreement with Islam et al. (2002), Ducatez et al. (2006, 2008), Craig et al. (2009), Kim et al. (2010) and Snoeck et al. (2012).

On the other hand, the CLEVB-Zag2 CAV was found to be $100 \%$ identical to $2 \mathrm{CAV}$ of high virulence from India of accession numbers KJ620993 and KJ620995 and one CAV isolate of high virulence from South Korea of accession number HM018735 and finally, the vaccinal strain Noblis P4.

The obtained results of pathogenecity studies of CLEVB-Zag2 CAV in one day old SPF chicks showed high virulence in the form of retardation of body weight gain and sever anaemia. Lowest body weights and haematocrite values were detected $7^{\text {th }}$ and $14^{\text {th }}$ days PI the histopathological lesions detected in thymus, bursa, spleen, liver and bone marrow were similar in frequency at days 7 and 14 PI indicating sever destruction of the lymphoid tissue. The weights of thymus and bursa were substantially reduced compared to the noninoculated birds at day 7 and day 14 PI these findings agreed with the findings of Toro et al. (1997). 
Studying the immunosuppressive potential of the CLEVB-Zag2 CAV on the immune response of SPF chicks against H5NI vaccine, the results indicated that our isolate was highly virulent and induce significant reduction in the protection percentage $(50 \%)$, the variance in the titer of the shed challenge $\mathrm{H} 5 \mathrm{~N} 1$ virus $(1.45 \log 10)$ and the mean $\mathrm{HI}$ titer at the $4^{\text {th }}$ week PV $(1.5 \log 2)$ compared with the noninfected vaccinated group where 90\%, $2.35 \log 10$ and $5.3 \log 2$ for the protection percentage, variance in the titer of the sheded challenge $\mathrm{H} 5 \mathrm{~N} 1$ virus and Mean HI titer; respectively (Tables 3-5). Our results agreed with those obtained by Hagood et al. (2000), Senthilkumar et al. (2002), Miller and Schat (2004), Dhama et al. (2008) and Hoerr (2010) who reported that infections with CAV generally cause severe and acute clinical disease in young chicks up to 34 weeks of age, after which age resistance to clinical infection has been reported to develop. Sub-clinical and persistent latent viral infections occurring in adult broiler and layer chickens are associated with production losses and vaccination failures.

In the same context, we could attribute this reduction in the immune response (vaccination failure)-in the experimental group infected with CAV to the sever destruction of the lymphoid tissue specially thymus, almost same explanation was recorded (Box et al., 1988), who stated that the effect on the thymus may be the underlying cause of the impaired response to inactivated Newcastle disease vaccine. The Same findings were recorded by de Boer et al. (1994) who stated that the aggravating effect of CAV on other viruses is mainly caused by impairment of other T-cell-mediated immune functions (other than T-helper cells), which leads to enhancing or transactivating of the virus replication of the other virus.

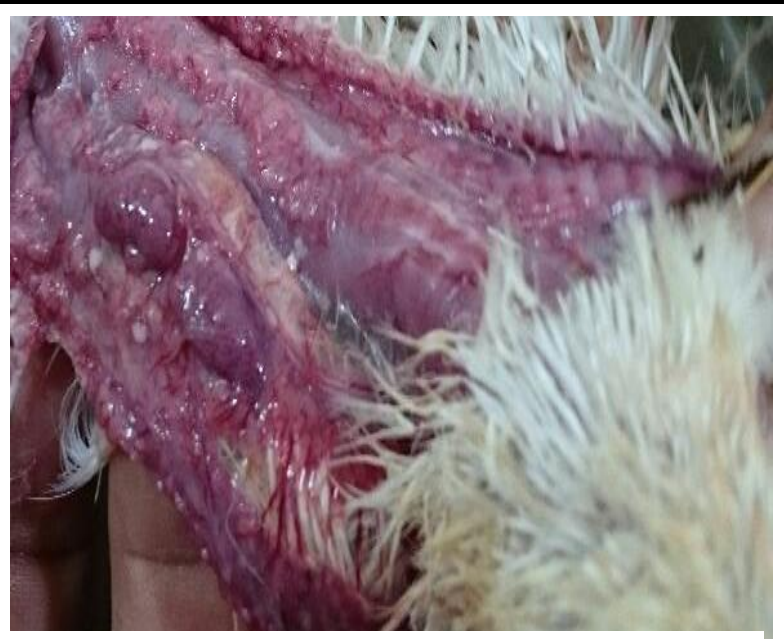

Fig. 1. Died broiler chicken of 35 day old.

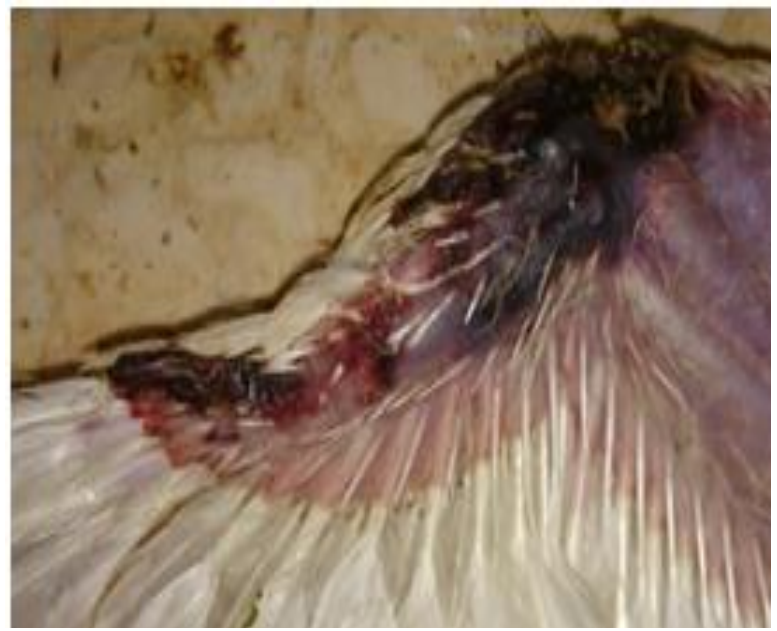

Fig. 2. Died broiler chicken of 35 day old with blue wing showed atrophied and congested thymus.

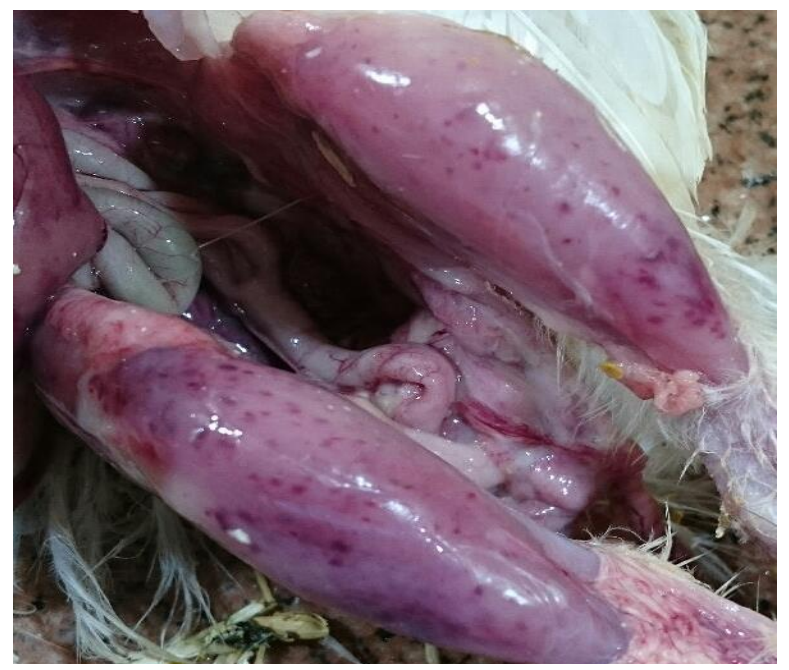

Fig. 3. Died broiler chicken of 35 day old showing intramuscular hemorrhages in leg muscles. 


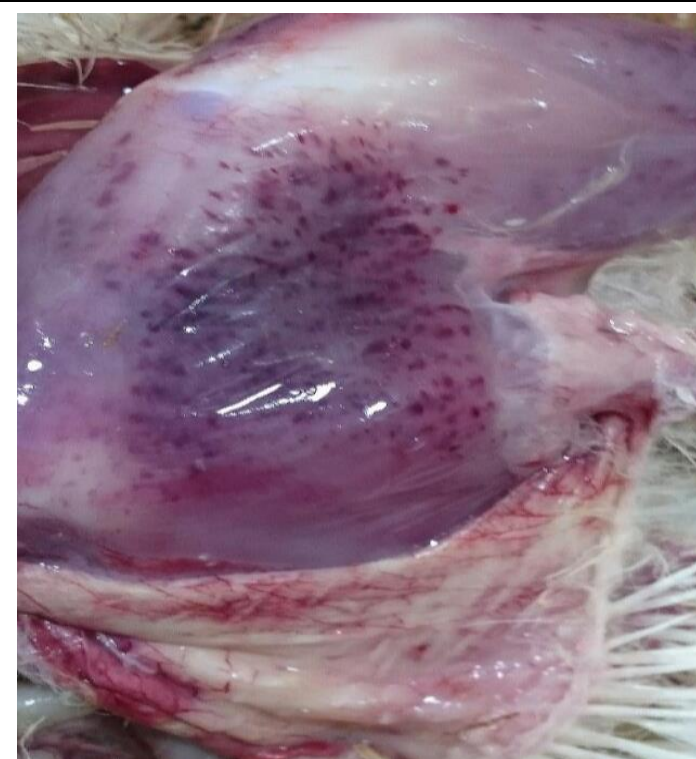

Fig. 4. Died broiler chicken of 35 day old showing intramuscular hemorrhages at thigh muscles.

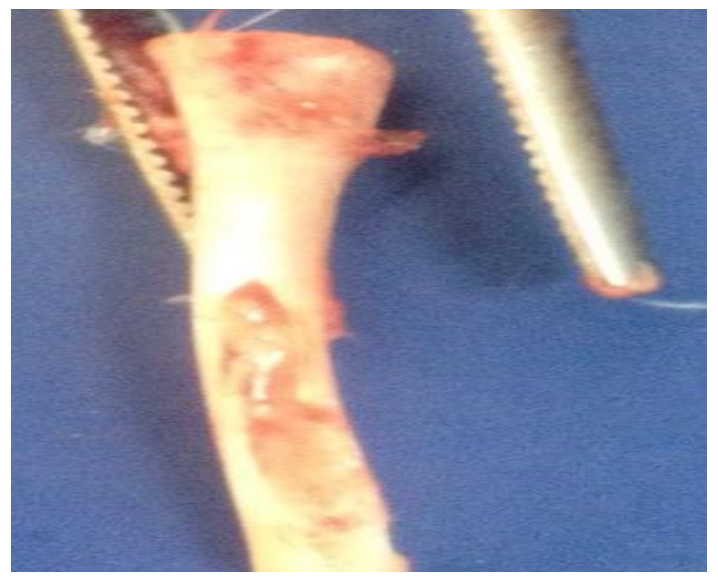

Fig. 6. Femur bone of 14-day-old SPF chicken experimentally infected with CAV showing yellowish bone marrow.

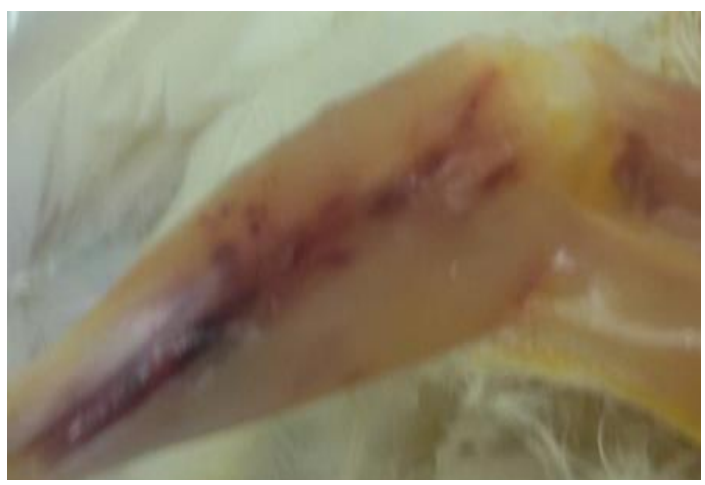

Fig. 8. Wing of 14-day-old SPF chicken experimentally infected with CAV showing hemorrhages at the feather tips.

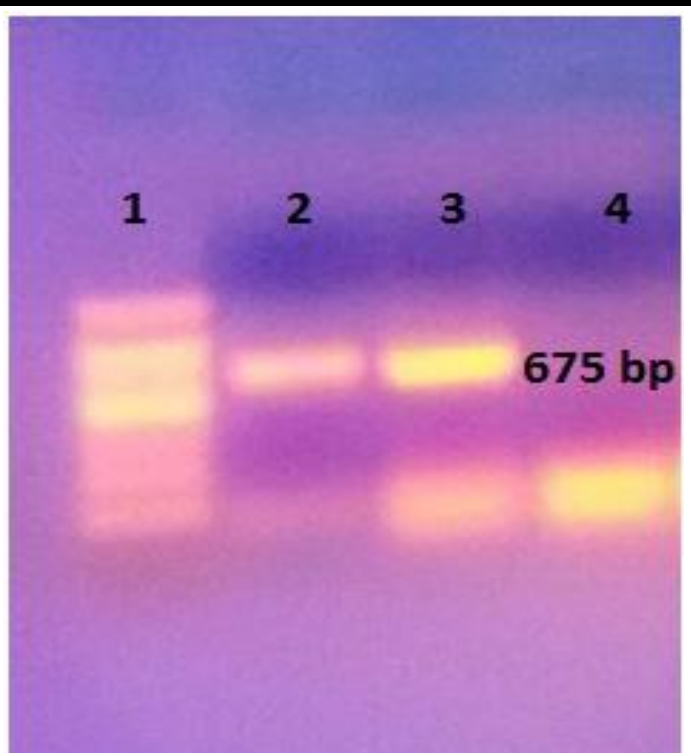

Fig. 5. PCR products of 675 bp length. Lane 1: 100 bp DNA ladder. Lane 2: CAV vaccine CUX-1 strain Lane 3: The CAV field isolate. Lane 4: Negative control.

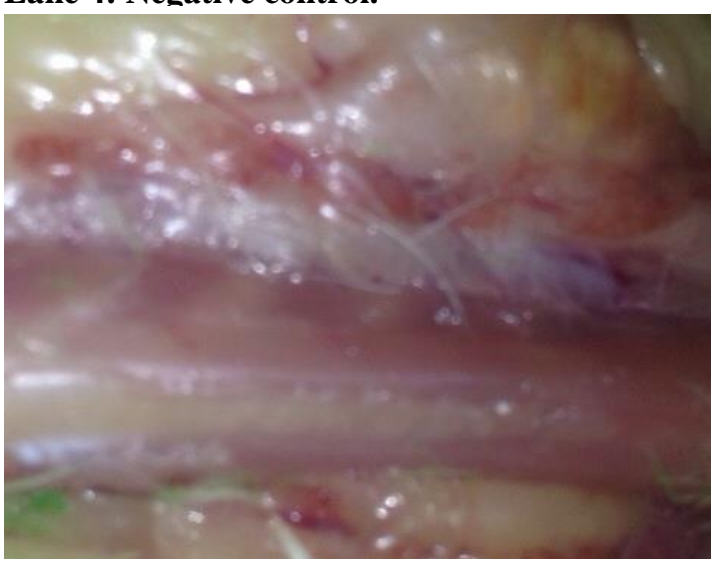

Fig. 7. Thymus of 14-day-old SPF chicken experimentally infected with CAV showing atrophy and congestion.

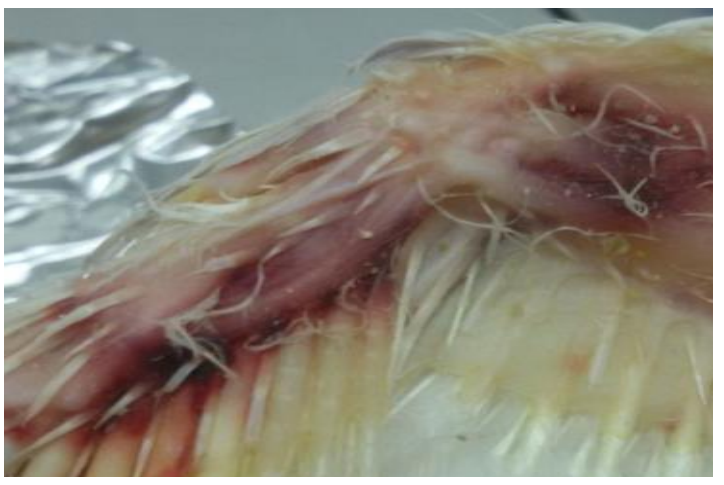

Fig. 9. Leg of 14-day-old SPF chicken experimentally infected with CAV showing intramuscular hemorrhage. 


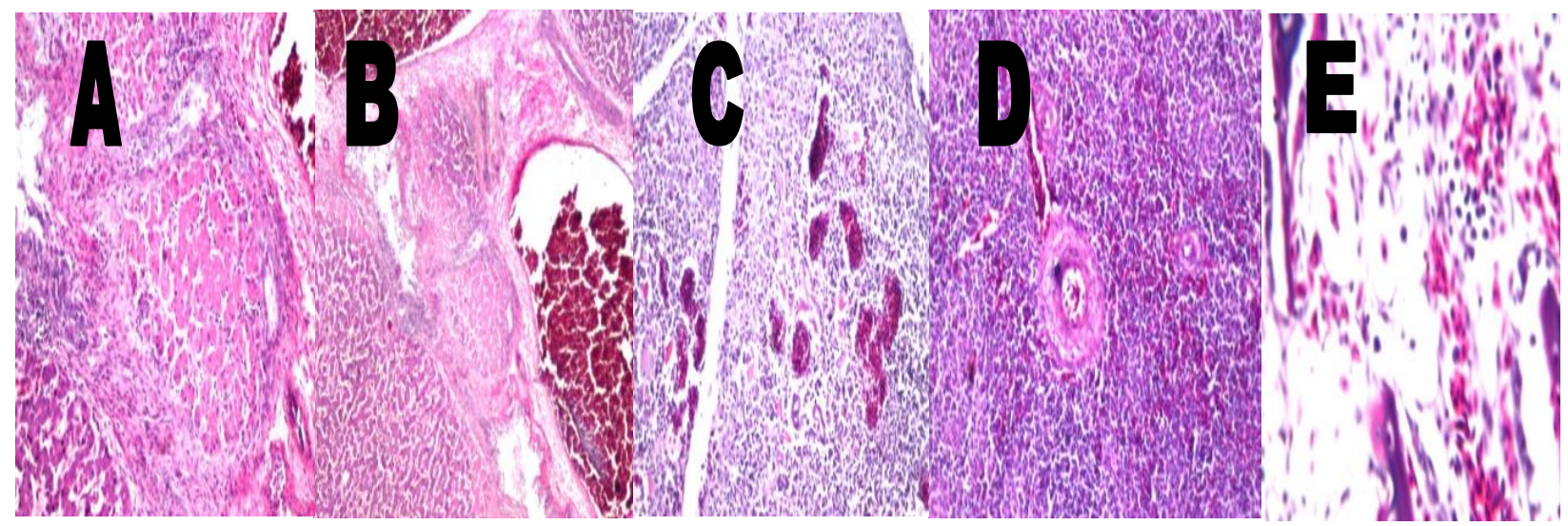

Fig. 10. Histopathological findings of the liver. A \& b) showed severe congestion in the portal vein associated with focal necrosis as well as inflammatory cells infiltration. C) Thymus showed lymphoid depletion in both cortical and medullary portions with congestion in the blood vessel. D) Spleen showed lymphoid depletion in the white pulps while the red one was congested. E) Bone marrow showed severe depletion in the erythrocytes as well as the other haemoblasts, 7 day old SPF chick inoculated with CLEVB-Zag2 CAV. (HE, $160 \mathrm{X})$.

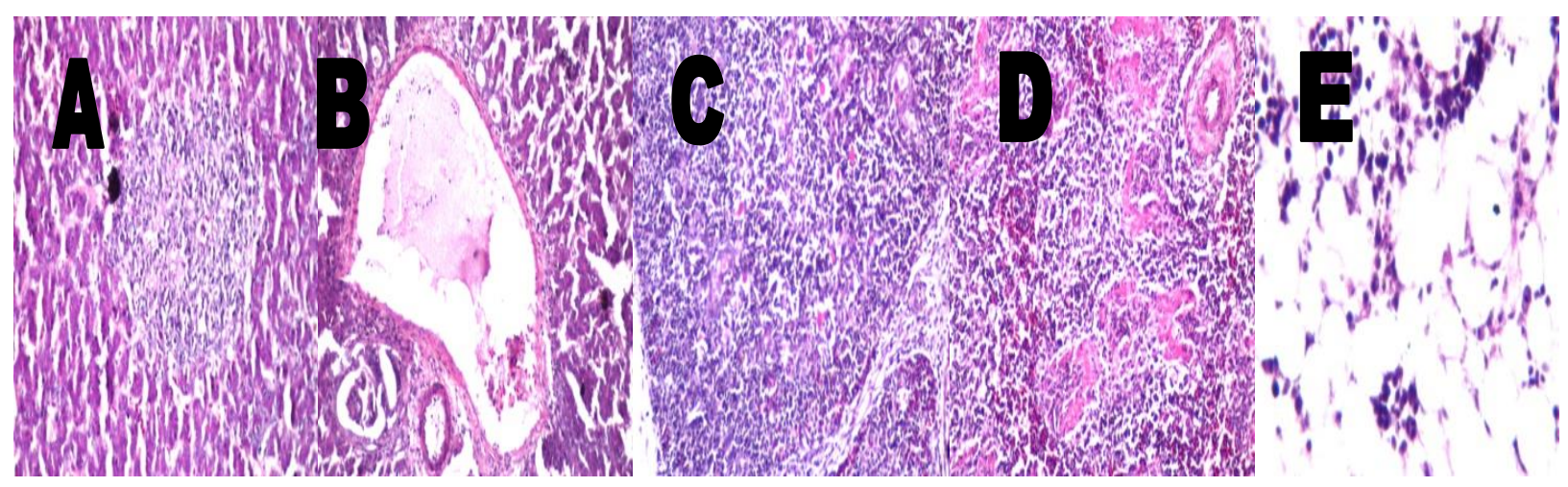

Fig. 11. Histopathological findings of the liver. A) Focal lymphoid cell aggregations in the hepatic parenchyma. B) Severe dilatation and congestion in the portal vein. C) Thymus showed depletion in both cortical and medullary lymphoid structure. D) Spleen showed focal necrosis in diffuse manner allover the white pulps. E) The bone marrow showed severe depletion in diffuse manner allover the erythrocytes as well as the haemoblasts with inflammatory cells infiltration, at the 14th day PI (HE, 160X).

Table 1. Hematological picture of the SPF chicken group inoculated with the CAV isolates

\begin{tabular}{ccccc}
\hline $\begin{array}{c}\text { Chicken age } \\
\text { (Days) }\end{array}$ & $\begin{array}{c}\text { Chicken } \\
\text { Group }\end{array}$ & PCV $(\%)$ & HB $(\mathrm{g} / \mathrm{dl})$ & $\begin{array}{c}\mathrm{RBCs} \\
\left(\mathrm{X} 10^{6}\right) / \mathrm{mm}\end{array}$ \\
\hline \multirow{2}{*}{7} & $\mathrm{G} 1$ & $17.8 \pm 2 *$ & $3.6 \pm 0.6 *$ & $1.44 \pm 0.01 *$ \\
\cline { 2 - 5 } & $\mathrm{C}$ & $35.2 \pm 0.55$ & $8.81 \pm 0.8$ & $2.3 \pm 0.16$ \\
\hline \multirow{2}{*}{14} & $\mathrm{G} 1$ & $12.9 \pm 2.2 *$ & $3.1 \pm 0.12 *$ & $0.89 \pm 0.15$ \\
\cline { 2 - 5 } & $\mathrm{C}$ & $35.1 \pm 0.79$ & $8.78 \pm 0.40$ & $2.19 \pm 0.16$ \\
\hline G1: Infected group with CAV, C: Control group, * Significant difference Mean $\pm \mathrm{SD}$
\end{tabular}


Table 2. Organ/body weight ratio and index of SPF chicken group experimentally infected with the CAV strain.

\begin{tabular}{|c|c|c|c|c|c|c|c|c|}
\hline \multirow{2}{*}{$\begin{array}{c}\text { Age } \\
\text { (Days) }\end{array}$} & \multirow[b]{2}{*}{ Group } & \multirow{2}{*}{$\begin{array}{c}\text { Body } \\
\text { weight }\end{array}$} & \multicolumn{3}{|c|}{ Thymus } & \multicolumn{3}{|c|}{ Bursa } \\
\hline & & & Weight & $\begin{array}{c}\text { Ratio } \\
(\mathrm{mg} / \mathrm{G})\end{array}$ & Index & Weight & $\begin{array}{c}\text { Ratio } \\
(\mathrm{mg} / \mathrm{G})\end{array}$ & Index \\
\hline \multirow{2}{*}{7} & G1 & $45.55 \pm 2.24$ & $0.16 \pm 0.02$ & 3.5 & \multirow{2}{*}{0.67} & $0.08 \pm 0.02$ & 1.75 & \multirow{2}{*}{0.44} \\
\hline & $\mathrm{C}$ & $57.9 \pm 2.21$ & $0.3 \pm 0.02$ & 5.2 & & $0.18 \pm 0.02$ & 3.95 & \\
\hline \multirow{2}{*}{14} & G1 & $66.11 \pm 3.11$ & $0.11 \pm 0.03$ & 1.6 & \multirow{2}{*}{0.29} & $0.15 \pm 0.02$ & 2.27 & \multirow{2}{*}{0.664} \\
\hline & $\mathrm{C}$ & $81.71 \pm 2.28$ & $0.45 \pm 0.03$ & 5.5 & & $0.28 \pm 0.02$ & 3.42 & \\
\hline
\end{tabular}

G1: Infected group with CAV $\quad$ C: Control group (Mean \pm SD)

\section{Table 3. Protection percentage of different vaccinated groups challenge with highly pathogenic avian influenza (HPAI) H5N1 virus.}
Group No. of challenged birds
Mortality
Protection $(\%)$

\begin{tabular}{cccc}
\hline $\mathrm{G} 1$ & 20 & 10 & 50 \\
\hline $\mathrm{G} 2$ & 20 & 2 & 90 \\
\hline $\mathrm{C}$ & 20 & 20 & 0 \\
\hline
\end{tabular}

G1: Infected group with CAV then vaccinated group with $\mathrm{H} 5 \mathrm{~N} 1$

G2: Non infected vaccinated group with H5N1 only

C: Control group

Table 4. Shedding titer variation between the negative non-vaccinated challenged and vaccinated challenged groups.

\begin{tabular}{ccc}
\hline Group & Protection $(\%)$ & Variation \\
\hline G1 & 50 & 1.425 \\
\hline G2 & 90 & 2.35 \\
\hline C & 0 & 0 \\
\hline
\end{tabular}

G1: Infected group with CAV then vaccinated group with H5N1

G2: Non infected vaccinated group with H5N1 only

C: control group

Table 5. Mean HI antibody titers (Log2)against the heterologous A/Chicken/Eg

1575S/2015 HPAI H5N1 antigen of SPF chickens vaccinated with AI vaccines

\begin{tabular}{cccccc}
\multirow{2}{*}{ Group } & \multicolumn{4}{c}{ Mean HI titers during the post vaccination period (Days post vaccination) } \\
\cline { 2 - 6 } & 0 & $7^{\text {th }}$ & $14^{\text {th }}$ & $21^{\text {st }}$ & $28^{\text {th }}$ \\
\hline G1 & 0 & 0 & 0.9 & 1.1 & 1.5 \\
\hline G2 & 0 & 0.6 & 1.5 & 2.8 & 5.3 \\
\hline C & 0 & 0 & 0 & 0 & 0 \\
\hline
\end{tabular}

G1: infected group with CAV then vaccinated group with H5N1

G2: non infected vaccinated group with $\mathrm{H} 5 \mathrm{~N} 1$ only

C: Control group 


\section{Conclusion}

The present study showed that the CLEVB-Zag2 CAV isolate is highly pathogenic and immunosuppressive virus. Moreover, our results suggest that further studies on the CIA vaccine are needed to elucidate the relationship between vaccine efficacy and wild strains as well as further studies related to reversion of vaccine virus to virulence.

\section{References}

Adair BM (2000). Immunopathogenesis of chicken anemia virus infection. Dev. Comp. Immunol.,24: 247-255.

Bancroft JD, Stevens A, Turner DR (1996). Theory and Practice of Histological Techniques. 4th edn., Churchill, Livingston, New York, London, San Francisco, Tokyo.

Bougiouklis PA, Sofia M, Brellou M, Georgopoulou I, Billinis A,.Vlemmas I (2007). A Clinical case of chicken infectious anemia disease and virus DNA detection in naturally infected broilers in Greece. Avian Dis., 51:639-664.

Box PG, Holmes, HC, Bushell AC, Finney PM (1988). Impaired response to killed Newcastle disease vaccine in chicken anaemia agent.Avian Pathol., 17, 713-723.

Buscaglia C, Crosetti CF, Nervi P (1994). Identification of chicken infectious anemia, isolation of the virus and reproduction of the disease in Argentina. Avian Pathol., 23(2):297304.

Craig MI, Rimondi A, Delamer M, Sansalone P, Konig G, Vagnozzi A, Pereda A (2009). Molecular characterization of chicken infectious anemia virus circulating in Argentina during 2007. Avian Dis., 53: 331-335.

Davidson I, Kedem M, Borochovitz H, Kass N, Ayali G, Hamzani E, Perelman B, Smith B, Perk S (2004). Chicken infectious anemia virus infection in Israeli commercial flocks: virus amplification, clinical signs, performance, and antibody status. Avian Dis., 48:108-118.

de Boer GF, Jeurissen SHM, Noteborn MHM, Koch G (1992). Biological aspects of Marek's disease virus infections as related to dual infections with chicken anaemia virus. 4th International Symposium on Marek's Disease, Amsterdam/Lelystad, Vol 1: 262-271. de Boer GF, Van Roozelaar DJ, Moormann RJ,
Jeurissen SHM, Van Den Wijngaard JC, Hilbink F, Koch G (1994). Interaction between chicken anaemia virus and live Newcastle disease vaccine. Avian Pathol., (23): 263-275.

Dhama K, Mahendran M, Somavanshi R, Chawak MM (2008). Chicken infectious anaemia virus: An immunosuppressive pathogen of poultry - A review. Indian J. Vet. Pathol., 32: 158-167.

Ducatez MF, Owoade AA, Abiola JO, Muller CP (2006). Molecular epidemiology of chicken anemia virus in Nigeria. Arch. Virol., 151:97111.

Ducatez M.F., H. Chen, Y. Guan, and C. P. Muller (2008): Molecular epidemiology of chicken anemia virus (CAV) in southeasternChinese live birds markets. Avian Dis., 52:68-73.

Engstrom BE (1988). Blue wing disease of chickens: isolation of avian reovirus and chicken anaemia agent. Avian Pathol., 17: 23-32.

Hagood LT, Kelly TF, Wright JC, Hoerr FJ (2000). Evaluation of chicken infectious anaemia virus and associated risk factors with disease and production losses in broilers. Avian Dis., 44: 803-808.

Hailemariam Z, Omar A, Hair-Bejo M, Giap TC (2008). Detection and characterization of chicken anemia virus from commercial broiler breeder chickens. Virol. J., 5:128. doi:10.1186/1743-422X-5-128.

Hoerr FJ (2010). Clinical aspects of immunosuppression in poultry. Avian Dis., 54: $2-15$.

Islam MR, Johne R, Raue R, Todd D, Muller H (2002). Sequence analysis of the full-length cloned DNA of a chicken anaemia virus(CAV) strain from Bangladesh: evidence for genetic CAV strains based on the deduced VP1 amino acid sequences. J. Vet. Med. B Infect. Dis. Vet. Public Health, 49:332-337.

Jeurissen SHM, de Boer GF (1993). Chicken anaemia virus influences the pathogenesis of Marek's disease in experimental infections depending on the dose of Marek's disease virus. Vet. Q., 14: 81-84.

Kim HR, Kwon YK, Bae YC, Oem JK, Lee OS (2010). Molecular characterization of chicken infectious anemia viruses detected from breeder and broiler chickens in South Korea. Poult. Sci, 89:2426-2431.

Ledesma N, Fehervari T, Casaubon MT, Lucio E, Ratz F (2001). Chicken infectious anemia in 
Mexico: virus identification and serology survey. Avian Dis., 45:788-796.

Lu Y-S, Tsai H-J, Kwang M-J, Tseng C-S (1993). Chicken infectious anemia in Taiwan: virus isolation and antibody survey. Exp. Rep. TPRIAH, 29: 81-89.

McIlroy SG, McNulty MS, Bruce DW, Smyth JA, 7 Goodall EA, Alcorn MJ (1992). Economic effects of clinical chicken anemia agent infection on profitable broiler breeder flocks. Avian Dis., 36: 566-574.

McNulty MS (1991). Chicken anemia agent: a review. Avian Pathol., 20: 187-203.

McNulty MS, Connor TJ, Mcneilly F, Todd D, Mawhinney KA, Creelan J, Mackie DP, Pollock D, Mcnair J, Curran WL, Mcloughlin MF (1989). Current status of chicken anemia agent. Proceedings of the 38th Western Poultry Disease Conference, pp. 12-13.

McNulty MS, Connor TJ, Mcneilly F, Mcloughlin MF, Kirkpatrick KS (1990). Preliminary characterization of isolates of chicken anaemia agent from the United Kingdom. Avian Pathol., 19: 67-73.

McNulty MS, McIlroy SG, Bruce DW, Todd D (1991). Economic effects of subclinical chicken anemia agent infection in broiler chickens. Avian Dis., 35: 263-268.

Miller MM, Ealey KA, Oswald WB, Schat KA (2003). Detection of chicken anemia virus DNA in embryonal tissues and eggshell membranes. Avian Dis., 47(3):662-671.

Miller MM, Schat KA (2004). Chicken infectious anaemia virus: an example of the ultimate hostparasite relationship. Avian Dis., 48:734-745.

Noteborn, MHM, de Boer GF, Van Roozelaar DJ, Karreman C, Kranenburg O, VOS JG, Jeurissen SHM, Hoeben RC, Zantema A, Koch G, Van Ormondt H, Van Dereb AJ (1991). Characterization of cloned chicken anemia viras DNA that contains all elements for the infectious replication cycle. J. Virol., 65: 3131-3139.

Noteborn MHM, Verschueren CAJ, Vanroozelaar DJ, Veldkamp S,Vandereb AJ, de Boer GF (1992). Detection of chicken anaemia virus (CAV) by DNA hybridization and polymerase chain reaction. Avian Pathol., 21: 107-111.

OIE Manual (2013). Manual of Standards of diagnostics test and vaccines for terrestrial animals. HA and HI test. http://www.fao.org/fileadmin/templates/rap/files/ me etings/2014/140318-reference.pdf

Oluwayelu DO, Todd D, Ball NW, Scott ANJ, Oladele OA, Emikpe BO, Fagbohun OA, Owoade AA, Olaleye OD (2005). Isolation and preliminary characterization chicken anaemia virus from chickens in Nigeria. Avian Dis., 49 (3): 446-450.

Otaki Y, Nunoya T, Tajima M, Kato A, Nomura Y (1988). Depression of vaccinal immunity to Marek's disease by infection with chicken anaemia agent. Avian Pathol.,17: 333-334.

Pope CR (1991). Chicken anemia agent. Vet. Immunol. Immunopathol., 30: 51-65.

Pope CR (1996). Lymphoid system. In C. Riddell (Ed.), Avian Histopathology, $2^{\text {nd }}$ ed. (pp.17-44). KennettSquare: American Association of Avian Pathologists.

Rosenberger JK, Cloud SS (1989). The effects of age, route of exposure, and coinfection with infectious bursal disease virus on the pathogenicity and transmissibility of chicken anemia agent (CAA). Avian Dis., 33:753-759.

Senthilkumar N, Kataria JM, Dhama K, Rahul S (2002). Day old specific pathogen free chick infected with chicken anaemia virus become carriers during the growing period. Indian J. Comp. Microbiol. Immunol. Infect. Dis., 23: 137-140.

Snoeck CJ, Komoyo GF, Mbee BP, Nakoune E, Le FaouA, Okwen MP, Muller CP (2012). Epidemiology of chicken anemia virus in Central African Republic and Cameroon. Virol. J., 9:189. doi: 10.1186/1743-422X-9-189.

Sommer F, Cardona C (2003). Chicken anemia virus in broilers: dynamics of the infection in two commercial broiler flocks. Avian Dis., 47:14661473.

Todd D, Connor TJ, Calvert VM, Creelan JL, Meehan BM, McNulty MS (1995). Molecular cloning of an attenuated chicken anaemia virus isolate following repeated cell culture passage. Avian Pathol., 24: 171-187.

Toro H, Ramirez AM, Larenas J (1997). Pathogenicity of chicken anaemia virus (isolate 10343) for young and older chickens. Avian Pathol., (26): 485-499.

Von Bulow V, Fuchs B, Vielitz E, Landgraf H (1983). Frühsterblichkeitssyndrom bei Küken nach Doppelinfektion mit dem Virus der 
Marekschen Krankheit (MDV) und einem Anamie-Erreger (CAA). Zentralbl. Veterinarmed. B, 30: 742-750.

Von Bulow V, Rudolph R, Fuchs B (1986).

Enhanced pathogenicity of chicken anemia agent (CAA) in dual infections with Marek's disease virus (MDV), infectious bursal disease virus (IBDV)or reticuloendotheliosis virus (REV). Zentralbl. Veterinarmed. B, 33: 93-116.

Yuasa N, Taniguchi T, Yoshida I (1979). Isolation and some proper ties of an agent inducing anaemia in chicks. Avian Dis., 23: 366-385.

Yuasa N, Taniguchi T, Imada T, Hihara H (1983). Distribution of chicken anemia agent (CAA) and detection of neutralizing antibody in chicks experimentally inoculated with CAA. Natl. Inst. Anim. Health Q. (Tokyo), 23:78-81.

Yuasa N, Imai K, Watanabe K, Saito F, Abe M, Komi K (1987). Aetiological examination of an outbreak of haemorrhagic syndrome in a broiler flock in Japan. Avian Pathol., 16:521-526.

Zhou W, Shen B, Yang B, Han S, Wei L, Xiao B, Zhou V (1997). Isolation and identification of chicken infectious anemia virus in China. Avian Dis., 41: 361-364. 